10 - ORIGINAL ARTICLE

Alimentary Tract

\title{
Polylactic acid film versus acellular porcine small intestinal submucosa mesh in peritoneal adhesion formation in rats $^{1}$
}

\author{
Filme ácido poli-lático versus tela de submucosa intestinal suína na formação de aderências \\ peritoneais em ratos
}

\author{
Ricardo Gonçalves da Costa ${ }^{\mathrm{I}}$, Marcelo Betancort Lontra' ${ }^{\mathrm{II}}$, Priscila Scalco ${ }^{\mathrm{III}}$, Leandro Totti Cavazzola ${ }^{\mathrm{IV}}$, Richard Ricachenewski \\ Gurskiv $^{\mathrm{V}}$ \\ ${ }^{I}$ MD, Fellow Master degree, Department of Medical Sciences, Faculty of Medicine, UFRS, Rio Grande do Sul, Brazil. \\ ${ }^{\text {II }} \mathrm{MD}$, Department of Medicine, Brazilian Luteran University, Faculty of Medicine, Brazilian Luteran University, Brazil. \\ III Graduate Student, Department of Medicine, Brazilian Luteran University, Faculty of Medicine, Brazilian Luteran University, Brazil. \\ ${ }^{\text {IV }} \mathrm{MD}, \mathrm{PhD}$, Professor of Morphology and Surgery, Department of Medicine, Brazilian Luteran University, Faculty of Medicine. Professor of Human \\ Anatomy, Federal University of Health Sciences, Porto Alegre - RS, Brazil. \\ ${ }^{v} \mathrm{MD}, \mathrm{PhD}$, Professor of Surgery and Medicine, Postgraduation Program, UFRS, Rio Grande do Sul, Brazil.
}

\begin{abstract}
Purpose: To assess intraperitoneal adhesion formation in rats after the single implantation of intraperitoneal polypropylene mesh versus SIS mesh, and the effect of PAF as a polypropylene mesh barrier. Methods: A total of 55 albino rats randomized into three groups were assessed. The type of adhesions, the percentage of mash covered with adhesions, and the rupture strength of the adhesions were evaluated. Results: The type 2 and 3 adhesions were more frequent in group 1 (polypropylene mesh) and group 3 (Polypropylene+PAF), while type 0 and 1 adhesions were more frequent in group 2 (SIS). The mean rupture strength was $1,58 \mathrm{~N}( \pm 0,719 \mathrm{~N})$ in group 1, 0,42 $\mathrm{N}$ $( \pm 0,432 \mathrm{~N})$ in group 2 and $1,23 \mathrm{~N}( \pm 0,432 \mathrm{~N})$ in group 3 . Over $50 \%$ of the mash was covered with adhesions in $12(80 \%)$ cases of the group 1 , in $4(20 \%)$ cases of the group 2 and in $16(84,2 \%)$ cases of the group 3 . Group 2 differed significantly ( $<<0.001)$ from the other groups. Conclusions: Implantation of intraperitoneal polypropylene mesh yielded higher rates of adhesion and the use of PAF as a mesh barrier didn't reduced the rates of adhesion. SIS mesh implantation revealed lower rates of peritoneal adhesions.
\end{abstract}

Key words: Polypropylenes. Surgical Mesh. Intraperitoneal Adhesions. Rats.

\section{RESUMO}

Objetivo: Avaliar a formação de aderência intraperitoneal em ratos após o implante peritoneal da tela de polipropileno comparada à tela de SIS, e o efeito do PAF como barreira anti-aderente à tela de polipropileno. Métodos: 55 ratos albinos foram randomizados em três grupos. O tipo de aderência, o percentual de tela coberta por aderência, e a força de rupturas das aderências foram avaliadas. Resultados: Os tipos de aderência 2 e 3 foram mais freqüentes no grupo 1 (polipropileno) e no grupo 3 (polipropileno+PAF); as do tipo 0 e 1 foram mais freqüentes no grupo 2 (SIS). A força media de ruptura foi de $1,58 \mathrm{~N}( \pm 0,719 \mathrm{~N})$ no grupo $1,0,42 \mathrm{~N}( \pm 0,432 \mathrm{~N})$ no grupo 2 e $1,23 \mathrm{~N}( \pm 0,432 \mathrm{~N})$ no grupo3. Mais de $50 \%$ da tela estava coberta por aderências em $12(80 \%)$ casos do grupo 1 , em $4(20 \%)$ casos do grupo 2 e em $16(84,2 \%)$ casos do grupo 3. O grupo 2 foi significativamente diferente $(p<0.001)$ dos outros grupos. Conclusões: O uso intraperitoneal da tela de polipropileno levou a elevados índices de aderência, e o uso de PAF como barreira anti-aderente não reduziu os índices de aderência. O implante intraperitoneal de SIS revelou índices baixos de aderências peritoneais. Descritores: Polipropilenos. Telas Cirúrgicas. Aderências. Ratos.

${ }^{1}$ Research performed at Experimental Laboratory of the Institute of Basic Health Sciences, Federal University of Rio Grande do Sul (UFRS), Brazil.

\section{Introduction}

Over two million abdominal procedures are performed in the United States every year. Incisional hernias have an incidence rate of 2 to $20 \%$ and a recurrence rate of 30 to $50 \%$ in primary closure $^{1}$. Trauma, infection, and tumors all can cause defects in the abdominal wall that are unable to be corrected without the use of prosthetic material, as autogenous tissue reconstruction is not sufficient $^{1,2}$. Furthermore, the use of prosthetic materials in abdomi- nal hernia repair has been shown to considerably improve surgical outcome $^{3,4}$. Nevertheless, dense adhesions of intraperitoneal viscera to the synthetic mesh are frequently reported ${ }^{4}$, and the direct contact of the mesh with the intestine is contraindicated as it induces the development of these adhesions and subsequent complications, such as intestinal obstruction and enterocutaneous fistula ${ }^{4}$. Development of a method that could prevent the viscera from adhering to the mesh and avoid complications could increase the safety in the videolaparoscopic repair of abdominal and inguinal hernias. 
This study assessed the formation of adhesions on the porcine small intestinal submucosa (SIS) mesh and the use of polylactic acid film (PAF) as polypropylene mesh barrier.

\section{Methods}

The study was performed at the Institute of Basic Health Sciences of Federal University of Rio Grande do Sul, Brazil in compliance with the guiding principles for research involving laboratory animals of the Council for International Organization of Medical Sciences (CIOMS) ethical code for animal experimentation and the principles of the Brazilian College on Animal Experimentation. The study protocol was approved by the local Research Ethics Committee.

Fifty five Wistar rats, each weighing approximately $200 \mathrm{~g}$, were randomized into three groups. All animals were anesthetized using an intramuscular injection of xylazine $(0.1 \mathrm{ml}$ of solution at $2 \%$ diluted in $0.2 \mathrm{ml}$ of physiological saline at $0.9 \%$ ) at a dose of $5 \mathrm{mg} / \mathrm{kg}$, and of ketamine $(0.35 \mathrm{ml}$ of solution at $50 \mathrm{mg} / \mathrm{ml})$ at a dose of $50 \mathrm{mg} / \mathrm{kg}$. After induction of anesthesia, abdominal hair was removed, and the surgical field was disinfected with $2 \%$ chlorhexidine alcohol.

A 3 to $4 \mathrm{~cm}$ midline laparotomy incision, with detachment of the subcutaneous space and opening of the peritoneal cavity along the linea alba, was performed on the animals. In the animals in group $1(\mathrm{n}=15)$, a polypropylene mesh $(2 \times 2 \mathrm{~cm})$ was placed equally distant from the midline opening. The mesh was fixated to the abdominal wall with polypropylene 4-0 transfixing sutures on the four mesh quadrants. The abdominal wall was then closed and the skin was sutured using polypropylene 3-0. In the animals from group $2(\mathrm{n}=20)$, a SIS mesh $(2 \times 2 \mathrm{~cm})$ was placed equidistant from the midline opening. The mesh was fixated to the abdominal wall with polypropylene 4-0 transfixing sutures on the four mesh quadrants, and the abdominal wall was closed and the skin was sutured using polypropylene $3-0$. In the animals from group $3(\mathrm{n}=20)$, a polypropylene mesh $(2 \times 2 \mathrm{~cm})$ was inserted equidistant from the midline opening. A PAF $(2.5 \times 2.5 \mathrm{~cm})$ was placed on the visceral side of the mesh. The mesh was fixated to the abdominal wall with polypropylene 4-0 transfixing sutures on the four mesh quadrants. The abdominal wall was closed and the skin was sutured using Polypropylene 3-0.

After the procedure, all animals were hydrated by subcutaneous administration of $5 \mathrm{ml}$ of physiological saline at $0.9 \%$, and allowed to recover in a separate, heated environment. After complete recovery from anesthesia, the animals were placed back in their cages.

On the 21st postoperative day, all animals were killed in a closed chamber with ether. Abdominal hair was removed and a U-shaped incision was made along the abdominal wall. The wall defect was repaired, and the wall was lifted to determine the percentage of mash covered with adhesion, if more or less than $50 \%$, because it was easier to be visualized in this size of mesh. The type of adhesion was assessed according to the scale described in Table 1.

At another stage, the affected site was repaired, and a $5 \mathrm{~N}$ dynamometer with a millimeter ruler was used to gauge the tensile strength.

All collected data were entered into a spreadsheet for later statistical analysis. The data were registered by two blinded observers, and if there were disagreement, the worst result was chosen.

The sample size was calculated according to data from the literature (2). The Kruskal-Wallis test was used for variables with score-based results, the chi-square test was used for nominal variables, and the analysis of variance (ANOVA) was used for continuous variables. The samples with $p<0.01$ were considered to be statistically significant. The SPSS (Statistical Package for Social Science) version 12.0 was used for statistical analyses. The study was completed within 6 months.

TABLE 1 - Classification of adhesions by direct visualization after U-shaped incision in the abdominal wall

\begin{tabular}{cl}
\hline Type of adhesion & \multicolumn{1}{c}{ Definition } \\
\hline 0 & No adhesions. \\
1 & Thin and easily disrupted adhesions. \\
2 & $\begin{array}{l}\text { Adhesions that require blunt dissection for disruption. } \\
\text { Dense adhesions that can only be broken up with the } \\
\text { use of considerable force, resulting in partial or total } \\
\text { injury to the viscera involved. }\end{array}$ \\
\hline
\end{tabular}




\section{Results}

All the animals in group $1(\mathrm{n}=15)$ developed adhesions. Only one animal had surgical wound infection, and the greater omentum was the most commonly involved viscera. In one case, the small intestine was severely adhered to the polypropylene mesh, and traction caused rupture of the intestinal segment.

Approximately $13.33 \%(n=2)$ of the animals had type 1 adhesions, whereas type 2 and type 3 adhesions were found in $33.33 \%(n=5)$ and $53.33 \%(\mathrm{n}=8)$ of the animals, respectively. No type 0 adhesions were observed. In $80 \%$ of cases, over $50 \%$ of the polypropylene mesh surface was covered with adhesions (Figure 1).

The mean tensile strength in group 1 was $1.58 \mathrm{~N}$ with a standard deviation of $0.719 \mathrm{~N}$. The mode and median was $1.5 \mathrm{~N}$, with the 25 th percentile at $1 \mathrm{~N}$ and the 75 th percentile at $2 \mathrm{~N}$. Table 2 shows the results for group 1, in which abdominal wall defects were repaired with only the polypropylene mesh.

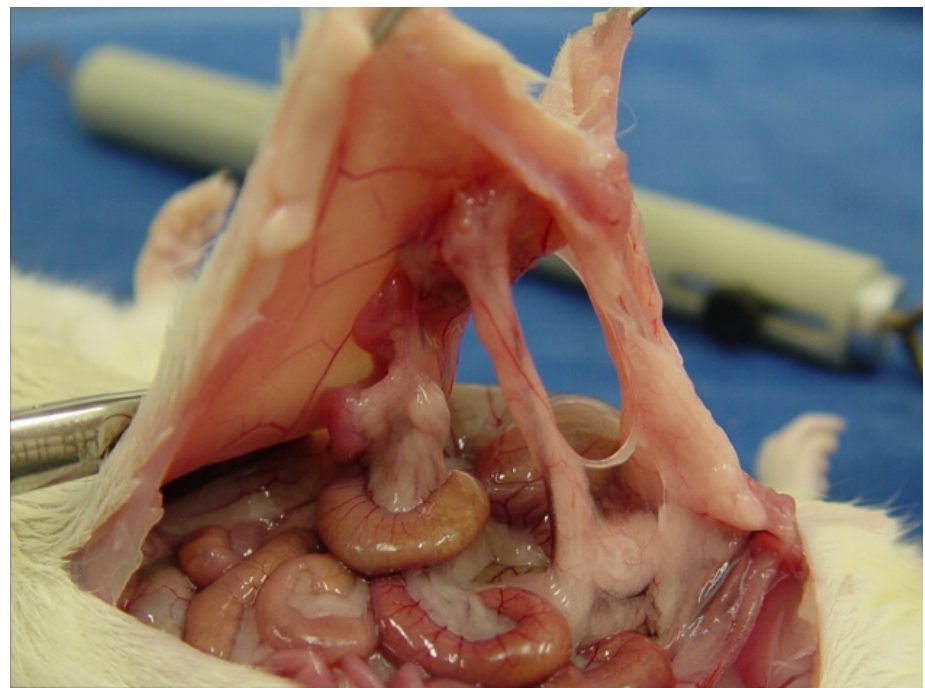

FIGURE 1 - Rat from group 1 with adhesions to the polypropylene mesh

TABLE 2 - Results obtained for Group 1

\begin{tabular}{|c|c|c|c|c|}
\hline $\begin{array}{l}\begin{array}{l}\text { Group 1 } \\
(\text { Marlex®) }\end{array} \\
\end{array}$ & $\begin{array}{l}\text { Involved } \\
\text { Organ } \\
\end{array}$ & $\begin{array}{l}\text { Type of } \\
\text { Adhesion }\end{array}$ & $\begin{array}{l}\% \text { of covered } \\
\text { mash }\end{array}$ & $\begin{array}{l}\text { Rupture Strength } \\
(\mathbf{N})^{3}\end{array}$ \\
\hline Rat 01 & Omentum & 1 & $>50 \%$ & 1,00 \\
\hline Rat 02 & $\begin{array}{l}\text { Small } \\
\text { intestine }\end{array}$ & 3 & $>50 \%$ & 3,00 \\
\hline Rat 03 & Omentum & 3 & $<50 \%$ & 3,00 \\
\hline Rat 04 & Omentum & 2 & $>50 \%$ & 1,00 \\
\hline Rat 05 & Omentum & 3 & $<50 \%$ & 1,00 \\
\hline Rat 06 & Omentum & 3 & $>50 \%$ & 1,50 \\
\hline Rat 07 & Omentum & 1 & $>50 \%$ & 1,00 \\
\hline Rat 08 & Omentum & 2 & $>50 \%$ & 1,50 \\
\hline Rat 09 & Omentum & 3 & $>50 \%$ & 2,00 \\
\hline Rat 10 & Omentum & 3 & $>50 \%$ & 1,50 \\
\hline Rat 11 & Omentum & 2 & $>50 \%$ & 1,50 \\
\hline Rat 12 & Omentum & 2 & $>50 \%$ & 1,20 \\
\hline Rat 13 & Omentum & 3 & $>50 \%$ & 2,50 \\
\hline Rat 14 & Omentum & 2 & $>50 \%$ & 1,00 \\
\hline Rat 15 & Omentum & 3 & $<50 \%$ & 1,00 \\
\hline Valid $=15$ & & Medium $=3$ & $\begin{array}{c}>50 \%=80 \% \\
(n=12)^{2}\end{array}$ & $\begin{array}{l}\text { Mean }=1,58 \\
\mathrm{SD}^{4}=0,719\end{array}$ \\
\hline
\end{tabular}

${ }^{1}$ Types of frequently observed adhesions; ${ }^{2}$ Percent of animals with over $50 \%$ of the mesh surface covered by adhesions; ${ }^{3}$ Rupture tensile strength in Newtons; ${ }^{4}$ Standard deviation.

Among the 20 animals in group 2, 35\% $(n=7)$ did not have adhesions. Only one animal presented with surgical wound hematoma, and the greater omentum was the only viscera involved. Approximately $35 \%(n=7)$ of the animals had type 0 adhesions, whereas $40 \%(n=8)$ and $25 \%(n=5)$ showed type 1 and type 2 adhesions, respectively. No type 3 adhesions were observed. In only $20 \%$ of cases did the porcine intraperitoneal small intestinal submucosa mesh show adhesions on over $50 \%$ of its surface (Figure 2). 


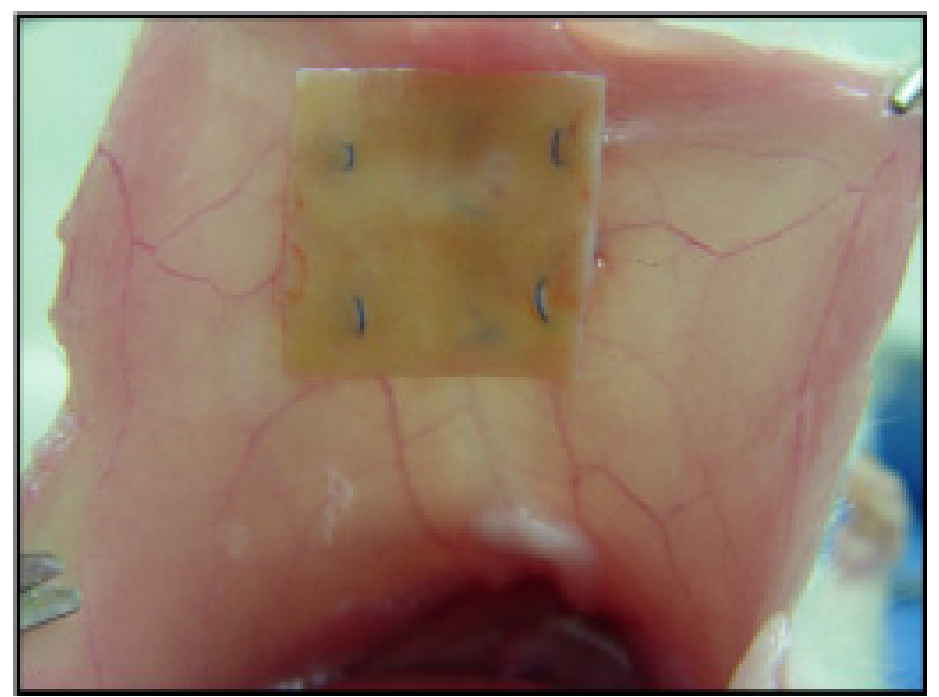

FIGURE 2 - Rat from group 2 with adhesions to the SIS mesh

The mean tensile strength in group 2 was $0.42 \mathrm{~N}$ with a standard deviation of $0.432 \mathrm{~N}$. The mode and median ranged from 0 to $0.25 \mathrm{~N}$, with the 25 th percentile at $0 \mathrm{~N}$ and the 75 th percentile at
$0.69 \mathrm{~N}$. Table 3 shows the results for group 2, in which abdominal wall defects were repaired with only the porcine small intestinal submucosa mesh.

TABLE 3 - Results obtained for Group 2

\begin{tabular}{|c|c|c|c|c|}
\hline $\begin{array}{l}\text { Group } 2 \\
\text { (SIS) }\end{array}$ & $\begin{array}{l}\text { Involved } \\
\text { Organ }\end{array}$ & $\begin{array}{l}\text { Type of } \\
\text { Adhesion }\end{array}$ & $\begin{array}{l}\% \text { of covered } \\
\text { mash }\end{array}$ & $\begin{array}{l}\text { Rupture Strength } \\
(\mathrm{N})^{\mathbf{3}}\end{array}$ \\
\hline Rat 01 & Omentum & 1 & $<50 \%$ & 1,25 \\
\hline Rat 02 & No adhesion & 0 & $<50 \%$ & 0,00 \\
\hline Rat 03 & Omentum & 2 & $<50 \%$ & 1,00 \\
\hline Rat 04 & No adhesion & 0 & $<50 \%$ & 0,00 \\
\hline Rat 05 & Omentum & 2 & $<50 \%$ & 0,50 \\
\hline Rat 06 & Omentum & 1 & $<50 \%$ & 0,20 \\
\hline Rat 07 & Omentum & 1 & $<50 \%$ & 0,20 \\
\hline Rat 08 & Omentum & 2 & $>50 \%$ & 1,00 \\
\hline Rat 09 & Omentum & 1 & $<50 \%$ & 0,75 \\
\hline Rat 10 & Omentum & 1 & $<50 \%$ & 0,50 \\
\hline Rat 11 & No Adhesion & 0 & $<50 \%$ & 0,00 \\
\hline Rat 12 & No Adhesion & 0 & $<50 \%$ & 0,00 \\
\hline Rat 13 & Omentum & 1 & $<50 \%$ & 0,50 \\
\hline Rat 14 & Omentum & 1 & $<50 \%$ & 0,50 \\
\hline Rat 15 & No Adhesion & 0 & $<50 \%$ & 0,00 \\
\hline Rat 16 & Omentum & 1 & $>50 \%$ & 0,50 \\
\hline Rat 17 & No Adhesion & 0 & $<50 \%$ & 0,00 \\
\hline Rat 18 & Omentum & 2 & $>50 \%$ & 0,25 \\
\hline Rat 19 & No Adhesion & 0 & $<50 \%$ & 0,00 \\
\hline Rat 20 & Omentum & 2 & $>50 \%$ & 1,25 \\
\hline Valid $=20$ & & Medium= & $\begin{array}{c}>50 \%=20 \% \\
(n=4)^{2}\end{array}$ & $\begin{array}{l}\text { Mean }=0,42 \\
\mathrm{SD}^{4}=0,432\end{array}$ \\
\hline
\end{tabular}

${ }^{1}$ Types of frequently observed adhesions; ${ }^{2}$ Percent of animals with over $50 \%$ of the mesh surface covered by adhesions; ${ }^{3}$ Tensile strength in Newtons; ${ }^{4}$ Standard deviation. 
All the animals in group $3(n=19)$ had adhesions. No animal presented with surgical wound complications; however, the PAF showed displacement in two rats. The greater omentum $(100 \%, n=19)$, the liver $(21.05 \%, n=4)$, and the small intestine $(5.26 \%, \mathrm{n}=1)$ were the most commonly involved viscera. One animal died from complications caused by anesthesia and was excluded from the study.

No animal showed type 0 or type 1 adhesions; type 2 adhesions were found in $42.1 \%(\mathrm{n}=8)$ of the rats, and type 3 adhesions in $57.9 \%(n=11)$. In $84,2 \%$ of cases, the PAF showed adhesions on over $50 \%$ of its surface (Figure 3 ). The mean tensile strength in group 3 was $1.23 \mathrm{~N}$ with a standard deviation of $0.432 \mathrm{~N}$. The mode and median ranged from $1 \mathrm{~N}$ to $1.2 \mathrm{~N}$, with the 25 th percentile at $0.9 \mathrm{~N}$ and the 75 th percentile at $1.5 \mathrm{~N}$. Table 4 shows the results for group 3, in which abdominal wall defects were repaired with Polypropylene mesh and PAF.

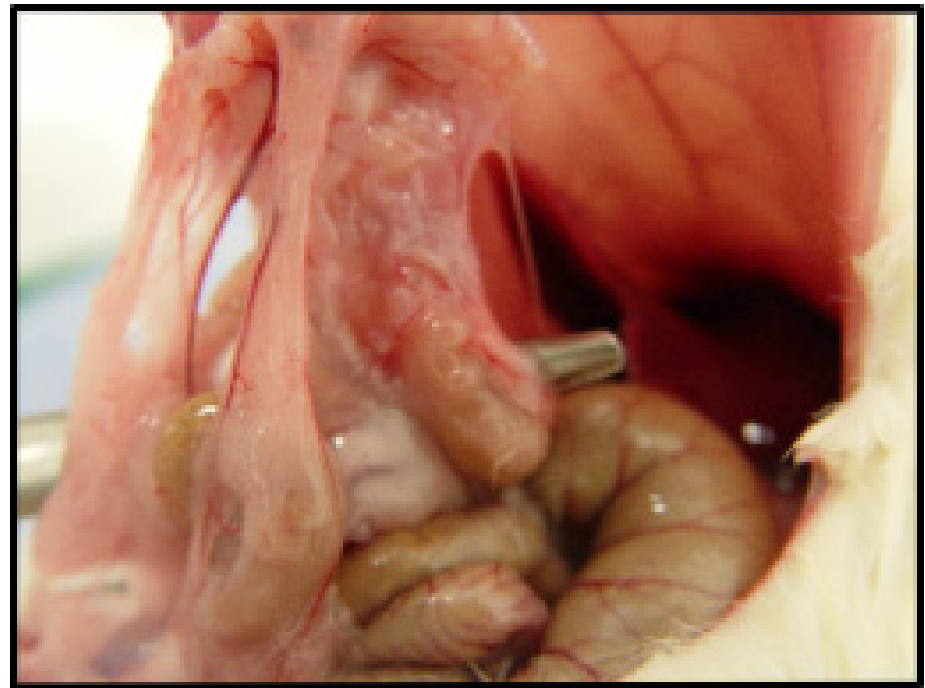

FIGURE 3 - Rat from group 3 with adhesions to the polypropylene mesh/ PAF.

TABLE 4 - Results obtained for Group 3

\begin{tabular}{|c|c|c|c|c|}
\hline Group 3 (PAF) & $\begin{array}{l}\text { Involved } \\
\text { Organ }\end{array}$ & $\begin{array}{l}\text { Type of } \\
\text { Adhesion }\end{array}$ & $\begin{array}{l}\text { \% of covered } \\
\text { mash }\end{array}$ & $\begin{array}{l}\text { Rupture Strength } \\
(\mathbf{N})^{3}\end{array}$ \\
\hline Rat 01 & Omentum & 3 & $>50 \%$ & 1,00 \\
\hline Rat 02 & $\begin{array}{l}\text { Liver, } \\
\text { Omentum }\end{array}$ & 3 & $>50 \%$ & 1,20 \\
\hline Rat 03 & Omentum & 3 & $>50 \%$ & 1,50 \\
\hline Rat 04 & Omentum & 3 & $>50 \%$ & 2,00 \\
\hline Rat 05 & Omentum & 3 & $>50 \%$ & 1,50 \\
\hline Rat 06 & Omentum & 2 & $>50 \%$ & 1,00 \\
\hline Rat 07 & Omentum & 2 & $>50 \%$ & 2,00 \\
\hline Rat 08 & Omentum & 3 & $>50 \%$ & 0,90 \\
\hline Rat 09 & Omentum & 2 & $>50 \%$ & 0,80 \\
\hline Rat 10 & Omentum & 2 & $<50 \%$ & 0,50 \\
\hline Rat 11 & $\begin{array}{l}\text { Liver, } \\
\text { Omentum }\end{array}$ & 2 & $>50 \%$ & 0,80 \\
\hline Rat 12 & $\begin{array}{l}\text { Liver, } \\
\text { Omentum }\end{array}$ & 3 & $>50 \%$ & 1,00 \\
\hline Rat 13 & Omentum & 3 & $>50 \%$ & 1,75 \\
\hline Rat 14 & Omentum & 3 & $>50 \%$ & 1,20 \\
\hline Rat 15 & Omentum & 2 & $>50 \%$ & 1,20 \\
\hline Rat 16 & Omentum & 2 & $<50 \%$ & 1,00 \\
\hline Rat 17 & Omentum & 3 & $>50 \%$ & 1,75 \\
\hline Rat 18 & $\begin{array}{l}\text { Liver, } \\
\text { Intestine, } \\
\text { Omentum }\end{array}$ & 3 & $>50 \%$ & 0,80 \\
\hline Rat 19 & Omentum & 2 & $<50 \%$ & 1,50 \\
\hline Valid $=19$ & & $\begin{array}{l}\text { Medium }= \\
3\end{array}$ & $\begin{array}{c}>50 \%= \\
84,2 \%(n=12)^{2}\end{array}$ & $\begin{array}{l}\text { Mean }=1,23 \\
\mathrm{SD}^{4}=0,432\end{array}$ \\
\hline
\end{tabular}

${ }^{1}$ Types of frequently observed adhesions; ${ }^{2}$ Percent of animals with over $50 \%$ of the mesh surface covered by adhesions; ${ }^{3}$ Tensile strength in Newtons; ${ }^{4}$ Standard deviation. 
The Kruskal-Wallis test revealed that groups 1 and 3 were statistically similar with regard to the type of adhesion, while group 2 differed significantly $(\mathrm{p}<0.001)$ from the other groups. This indicates that the group treated with SIS mesh had less severe adhesions than the other groups (Figure 4).

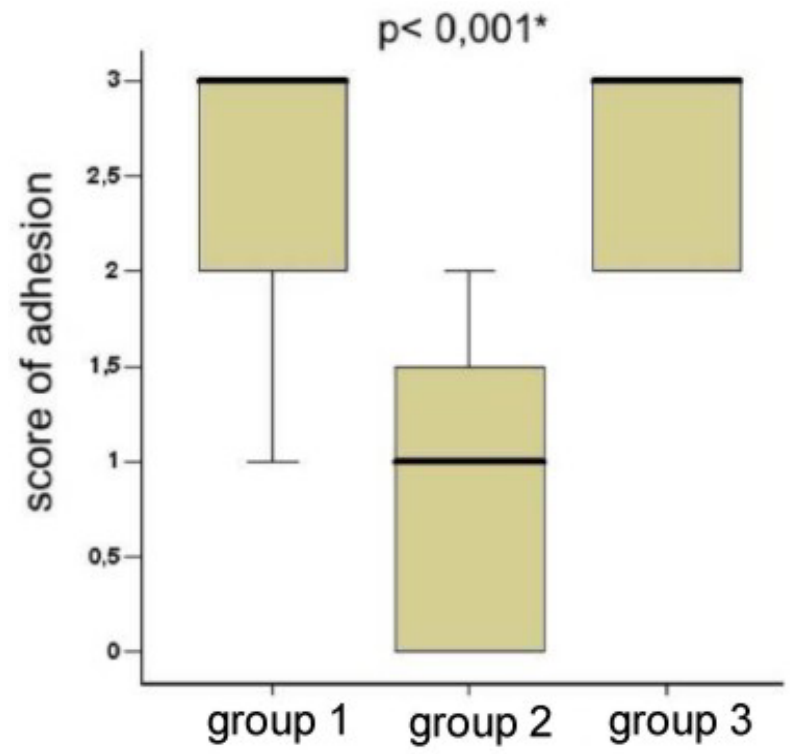

FIGURE 4 - Comparison of the rates of adhesions.

* Difference between Group 2 and Groups 1 and 3 is statistically significant $(\mathrm{p}<0.001)$

With regards to the severity of adhesions, the number of cases in which adhesions exceeded $50 \%$ of the mesh surface was similar in groups 1 and 3 (80\% and 84,2\%). In group 2, only $20 \%$ of the cases had over $50 \%$ of the mesh surface covered by adhesions, and the chi-square test confirmed this difference between group 2 and the others to be statistically significant $(\mathrm{p}<0.001)$ (Figure 5).

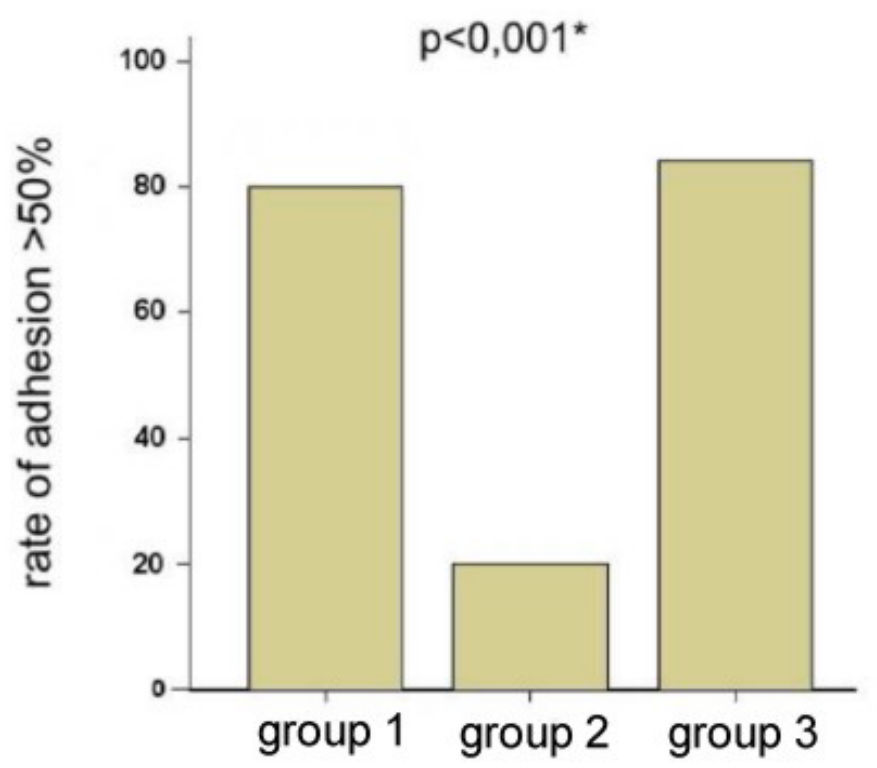

FIGURE 5 - Comparison of the rates of adhesion over 50\%.

* Difference between Group 2 and Groups 1 and 3 is statistically significant $(\mathrm{p}<0.001)$
Finally, tensile strength showed a similar trend among the groups, in that the data from groups 1 and 3 were not significantly different. However, ANOVA revealed a statistically significant $(p<0.001)$ difference between these groups and group 2 (Figure 6).

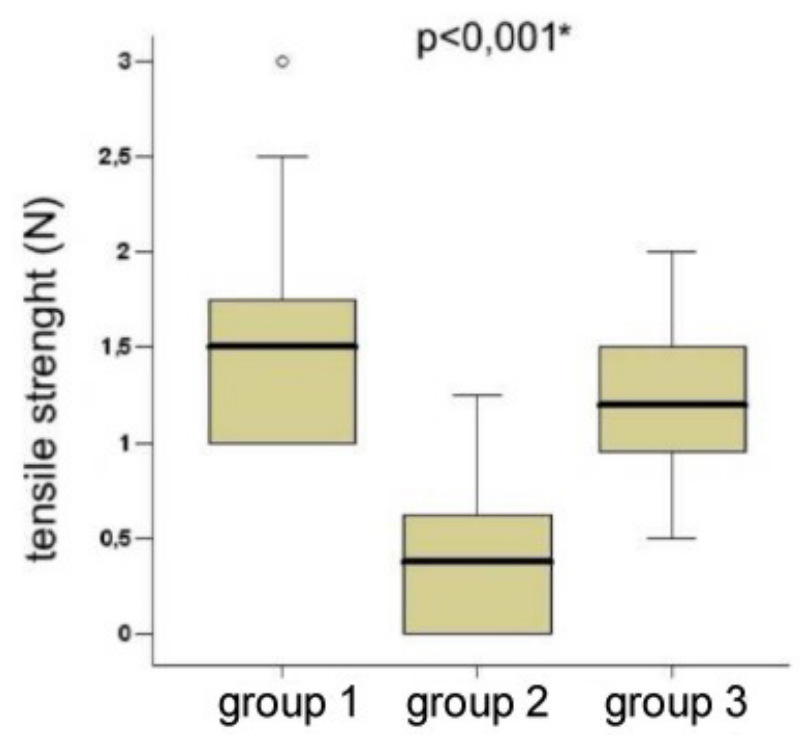

FIGURE 6 - Comparison of tensile strengths across groups.

* Difference between Group 2 and Groups 1 and 3 is statistically significant $(\mathrm{p}<0.001)$

\section{Discussion}

In the placement of mesh during the repair of abdominal wall defects, the mesh might not be sufficiently covered by the peritoneum, and occasionally the greater omentum may not be available for interposition between the abdominal viscera and the polypropylene mesh. In addition, laparoscopic repair of ventral hernias has been recently achieved by intraperitoneal implantation of the mesh directly in contact with the abdominal viscera ${ }^{5}$. The abdominal viscera injured by the procedure contacts the mesh and possible complications may develop from adhesions. Thus, preventing adhesions to the mesh can reduce the morbidity of complications caused by direct contact of the mesh with the abdominal viscera $^{2}$

The observations with group 1 in this study, with all animals presenting adhesions, are consistent with previously described results. Moreover, although the greater omentum was the most commonly affected site, the small intestine adhered to the polypropylene mesh in one case, and traction caused rupture of the intestinal segment. Approximately $86,6 \%$ of the animals in this group developed type 2 and type 3 adhesions, and in $80 \%$ of cases, more than $50 \%$ of the mesh surface was covered by adhesions. This finding contraindicates direct use of the intraperitoneal polypropylene mesh. This is widely known in clinical practice, and several studies have reported complications related to the use of intraperitoneal polypropylene mesh ${ }^{1,2}$.

Recently, composite polypropylene meshes have been introduced that include a protective barrier on the visceral side; the barrier prevents contact of the viscera with the mesh surface while 
allowing healing to occur on the parietal surface of the material ${ }^{1}$. Mechanical barriers between injured tissues and the mesh material have been investigated with thriving results.

The polylactic acid film (PAF) consists of a copolymer containing two forms of lactic acid ( ${ }_{\mathrm{L}}$-lactide and ${ }_{\mathrm{D}, \mathrm{L}}$-lactide). Given the variation in copolymer ratio, the manufacturer can control for the tensile strength and characteristics of material degradation ${ }^{6}$. The polymer is degraded by the body through hydrolysis followed by metabolism by the liver ${ }^{6}$. This polymer, which is broadly used in brain and orthopedic surgeries as absorbable films, induces little tissue ingrowth ${ }^{7}$. Although how the lactic acid film affects coagulation, epithelization, and fibrinolysis, which play a key role in adhesion formation, remains unknown, the efficacy of the material seems to be achieved by the interposition of injured surfaces during the critical period of adhesion formation ${ }^{8}$. The unique physical properties of PAF make it suitable for abdominal use. PAF is a flexible material that does not fold or crumple; moreover, it can be easily handled with moist or wet gloves, and consequently, the material does not adhere to the abdominal viscera or the abdominal wall. Fortunately, PAF is relatively strong and can be sutured without causing damage to its structure. The use of lactic acid film is associated with a reduction in adhesion rates and in the severity of adhesions ${ }^{8}$.

In this study, PAF failed to function as a protective mesh barrier, as all animals in group 3 developed adhesions. In addition, the involvement of the greater omentum $(100 \%, n=19)$, liver $(21.05 \%, n=4)$ and small intestine $(5.26 \%, n=1)$ suggests that this material induced a stronger adhesiogenic process. The formation of adhesions on over $50 \%$ of the mesh surface in $84,2 \%$ of group 3 animals and the presence of type 2 and type 3 adhesions in $100 \%$ of this group shows that the lactic acid film was not efficient as predicted.

Comparison of the utility and effects of the adhesions among the groups showed that groups 1 and 3 were statistically similar. Regarding the severity of adhesions, the number of cases in which more than $50 \%$ of the mesh surface was covered by adhesions was similar between groups 1 and 3 (80\% and 84,2\%). Finally, the tensile strength showed a similar trend between these groups, with no statistically significance difference between groups 1 and 3 .

The findings of this study on the use of PAF are not consistent with those from previously published reports. Nevertheless, no studies have shown an association between polypropylene mesh and polylactic acid film, and our results suggests that though PAF is efficient when used alone, it may not be efficient in combination with polypropylene mesh.

A new type of mesh consisting of porcine small intestinal submucosa (SIS) has been currently available for the repair of tissue defects 9 . This mesh consists of four layers and the material serves as a temporary mold for tissue growth, leading to the formation of a strong extracellular matrix ${ }^{9}$. Its chemical composition facilitates host cell migration and consequent incorporation of the mesh by the tissues ${ }^{10}$. As SIS is easily handled, nonsynthetic, and reabsorbable within 6 to 12 months, it is unlikely to cause visceral injuries ${ }^{9}$. Porcine small intestinal submucosa is an acellular graft constituted of type I collagen. Experimental evidence suggests that the extracellular matrix formed by SIS degrades quickly, but the remodeling tissue that replaces the matrix is stronger than the native tissue ${ }^{11}$.
When SIS was used as vascular graft in a canine model, complete endothelization took place within 28 days after implantation $^{10}$. In an Achilles tendon repair model, the tendons repaired with SIS exhibited a stratified, organized, collagen-rich connective tissue similar to that of the contralateral healthy control ${ }^{10}$. Therefore, these characteristics seem very appropriate for hernia repair.

The use of SIS in the repair of diaphragmatic defects has been successfully reported in several studies ${ }^{9,12}$, and clinical trials and comparative studies have demonstrated its efficient use in abdominal defect repair ${ }^{13,14,15}$. In a comparative study of polypropylene mesh and SIS, the latter material showed increased thickness within the first 14 days. Adhesion formation was significantly more intense in the polypropylene mesh group at 30 days and more extensive in the SIS group at 90 days. Tensile strength increased during the follow-up of groups treated with both materials, but was more significant in the SIS group at 30 days. Implants in the polypropylene mesh group were associated with an inflammatory response and more pronounced neovascularization. Collagen formation was initially more fibrous and improved in the polypropylene mesh group, but was larger in the SIS group at 90 days. Together this suggests that the biological mesh induces a less intense inflammatory response as well as differences in collagen deposition ${ }^{10}$.

In this study, $35 \%(n=7)$ of the animals in group 2 (SIS) did not develop adhesions. Furthermore, the greater omentum was the only site involved in adhesion formation. Approximately $35 \%$ $(n=7)$ of the animals formed type 0 adhesions, $40 \%(n=8)$ developed type 1 adhesions, and $25 \%(\mathrm{n}=5)$ had type 2 adhesions. No cases of type 3 adhesions were observed in this group. In only $20 \%$ of cases, the porcine small intestinal submucosa mesh was covered by adhesions in over $50 \%$ of its surface. The effects of the intraperitoneal SIS mesh differed significantly $(p<0.001)$ from the other mesh materials, with less severe adhesions, lower tensile strength, and lower adhesion rates.

Together, these findings indicate that SIS is a better alternative than the polypropylene mesh for the intraperitoneal repair of abdominal wall hernias and large defects, in which the contact of the mesh with the abdominal viscera is inevitable.

\section{Conclusions}

In this study, we assessed the rate of intraperitoneal adhesion formation. Use of intraperitoneal polypropylene mesh resulted in high rates of adhesion, as previously reported. Compared to the use of the intraperitoneal polypropylene mesh, the porcine small intestinal submucosa mesh (SIS) showed lower rates of peritoneal adhesions. Use of the polylactic acid film (PAF) as a mesh barrier using the combined intraperitoneal placement of polypropylene mesh and PAF revealed high rates of adhesion, which were similar to those found for the polypropylene mesh alone.

\section{References}

1. Van't Riet M, de Vos van Steenwijk PJ, Bonthuis F, Marquet RL, Steyerberg EW, Jeekel J, Bonjer HJ. Prevention of adhesion to prosthetic mesh. Ann Surg. 2003;237(1):123-8.

2. Alimoglu O, Akcakaya A, Sahin M, Unlu Y, Ozkan OV, Sanli E, Eryilmaz $\mathrm{R}$. Prevention of adhesion formations following repair of abdominal wall defects with prosthetic materials (an experimental study). Hepatogastroenterol. 2003;50:725-8. 
3. Novitsky YW, Harrell AG, Hope WW, Kercher KW, Heniford BT. Meshes in hernia repair. Surg Technol Int. 2007;16:123-7.

4. Halm JA, de Wall LL, Steyerberg EW, Jeekel J, Lange JF. Intraperitoneal polypropylene mesh hernia repair complicates subsequent abdominal surgery. World J Surg. 2007;31(2):423-9.

5. Heniford BT, Park A, Ramshaw BJ, Voeller G, Ramshaw BJ. Laparoscopic ventral and incisional hernia repair in 407 patients. J Am Coll Surg. 2000;190:645-50.

6. Claes LE, Ignatius AA, Rehm KE, Scholz C. new bioresorbable pin for the reduction of small bony fragments: design, mechanical properties and in vitro degradation. Biomaterials. 1996;17:1621-6.

7. Bessho K, Lizuka T, Murakami K. Bioabsorbable poly-lactide miniplate and screw system for osteosynthesis in oral and maxillofacial surgery. $\mathrm{J}$ Oral Maxillofac Surg. 1997;55:941-5.

8. Holmdahl L, Risberg B, Beck DE, Burns JW, Chegini N, diZerega GS, Ellis H. Adhesions: pathogenesis and prevention - panel discussion and summary. Eur J Surg. 1997;577(Suppl):58.

9. Oelschlager BK, Barreca M, Chang L, Pellegrini CA. The use of small intestine submucosa in the repair of paraesophageal hernias: initial observations of a new technique. Am J Surg. 2003;186:4-8.
10. Zhang F, Zhang J, Lin S, Oswald T, Sones W, Cai Z, Dorsett-Martin W, Lineaweaver WC. Small intestinal submucosa in abdominal wall repair after tram flap, harvesting in a rat model. Plast Reconstr Surg. 2003;112(2):565-70.

11. Baylak S, Kokini K, Tullius B, Whtson B. Strength over time of a resorbable bioscaffold for body wall repair in a dog model. J Surg Res. 2000;52:282-7.

12. Holcomb GW 3rd, Ostlie DJ, Miller KA. Laparoscopic patch repair of diaphragmatic hernias with Surgisis. J Pediatr Surg. 2005;40(8):E1-5.

13. Franklin ME Jr, Gonzalez JJ Jr, Glass JL. Use of porcine small intestinal submucosa as a prosthetic device for laparoscopic repair of hernias in contaminated fields: 2-year follow-up. Hernia. 2004;8(3):186-9.

14. Catena F, Ansaloni L, Leone A, De Cataldis A, Gagliardi S, Gazzotti F, Peruzzi S, Agrusti S, D'Alessandro L, Taffurelli M. Lichtenstein repair of inguinal hernia with Surgisis inguinal hernia matrix soft-tissue graft in immunodepressed patients. Hernia 2005;9(1):29-31.

15. Grethel EJ, Cortes RA, Wagner AJ, Clifton MS, Lee H, Farmer DL, Harrison MR, Keller RL, Nobuhara KK. Prosthetic patches for congenital diaphragmatic hernia repair: Surgisis vs Gore-Tex. J Pediatr Surg. 2006;41(1):29-33.

Conflict of interest: none

Financial source: none

\section{Correspondence:}

Ricardo Gonçalves da Costa

Rua Becker Pinto, 118/302

97050-070 Porto Alegre - RS Brazil

Phone: (55 51)9631-4191

ricardogoncalvescosta@gmail.com

\section{How to cite this article}

Costa RG, Lontra MB, Scalco P, Cavazzola LT, Gurski RR. Polylactic acid film versus acellular porcine small intestinal submucosa mesh in peritoneal adhesion formation in rats. Acta Cir Bras. [serial on the Internet] 2009 Mar-Apr;24(2).

Available from URL: http://www.scielo.br/acb

*Color figures available from www.scielo.br 